Original Paper

\title{
Efektivitas Penggunaan Dwibahasa dalam Proses Pembelajaran Matematika
}

\author{
Ni Ketut Sulastri $1^{*}$ \\ ${ }^{1}$ Sekolah Dasar Negeri 1 Sandik, Indonesia
}

DOI: https://doi.org/10.29303/jcar.v3i1.648

*Corresponding Author:

Ni Ketut Sulastri, Sekolah

Dasar Negeri 1 Sandik,

Indonesia.

Email:

nsulastri1965@gmail.com

\begin{abstract}
Abstrak: Kajian proses pembelajaran dengan menggunakan Dwibahasa sangat menarik untuk diteliti karena dalam kajiannya melibatkan semua aspek-aspek pembelajaran termasuk penggunaan bahasa pengantar. Dalam berintraksi antara guru dengan anak didik, bahasa pengantar yang merupakan salah satu penomena yang sangat menarik untuk diteliti.penggunaan Dwibahasa, Bahasa Sasak Bahasa Indonesia di kelas 1 SD Negeri 1 Sandik, juga merupakan penomena yang menarik untuk diteliti. Secara oprasional penelitian ini untuk menemukan sejauhmana Efektivitas penggunaan Dwibahasa, Bahasa Sasak Bahasa Indonsia dalam proses Pembelajaran Matematika di kelas 1 SD Negeri 1 Sandik. Untuk memperoleh data-data yang akurat pada penelitian menggunakan metode wawancaea dan metode post test. Berdasarkan data pada bab sebelumnya dapat disimpulkan bahwa efektivitas penggunaan dwibahasa dalam proses pembelajaran Matematika di kelas 1 SD Negeri 1 Sandik telah memenuhi indikator ketuntasan dimana kualitasnya baik melampaui $85 \%$ yaitu 90,62\% maka perbaikan pembelajaran ini dinyatakan tuntas dan hipotesis tindakan dinyatakan diterima yaitu sangat efektif penggunaan Dwibahasa dalam proses pembelajaran Matematika di kelas 1 SD Negeri 1 Sandik.
\end{abstract}

Kata kunci: Efektifitas; Dwibahasa; Matematika

\section{Pendahuluan}

Keberadaan bahasa di tengah-tengah proses belajar mengajar sangat diperlukan, karena tanpa bahasa tidak akan dapat terjadi intraksi antara guru dan murid, tidak bisa dilakukan tanpa menggunakan media bahasa dari proses belajar mengajar (Junaidi, 2018); (Umarella et al., 2018). Jadi dapat dikatakan bahwa masyarakat sekolah, terutama dalam kegiatan belajar menjadikan bahasa sebagai alat penghubung atau alat komunikasi yang sangat utama.

Tetapi pada kenyataannya penempatan guru kelas satu yang tidak pasih berbahasa Daerah, khususnya bahasa Sasak, dan guru
Matematika yang lebih condong berbahasa Indonsia, di samping itu latar belakang siswa yang rata-rata tidak tamat Taman KanakKanak, serta tidak lancar berbahasa Indonesaia terkadang menimbulkan intraksi satu arah, maksudnya siswa hanya mendengarkan penjelasan guru, hal ini memungkinkan siswa tak mengerti penjelasan guru. Begitu pula proses pembelajaran Matematika di kelas 1 SD Negeri 1 Sandik, siswa-siswinya lebih banyak pasif dalam menerima pelajaran, mereka duduk dan diam tak ada intraksi manakala guru menjelaskan dengan bahasa Indonesia. Tetapi jika guru menjelaskan dengan Dwibahasa, anak-anak banyak yang bertanya menggunakan bahasa ibunya. 
Mengingat gejala kemungkinan penggunaan dwibahasa, bahasa Sasak, dan Bahasa Indonesia sebagai bahasa penghantar dalam proses belajar mengajar tidak bisa dibiarkan begitu saja. Gejala ini memerlukan penanganan secara khusus oleh pemerintah dan pihak yang peduli terhadap pendidikan. Maka dalam kesempatan ini dilakukan penelitian tentang "Efektivitas Penggunaan Dwibahasa Dalam Proses Pembelajaran Matematika di Kelas 1 SD Negeri 1 Sandik. Tujuan penelitian ini adalah untuk merencanakan pembinaan dan pengembangan penggunaan bahasa pengantar Bahasa Sasak, Bahasa Indonesia dan Dwibahasa secara bergantian dalam proses pembelajaran Matematika.

\section{Metode}

\section{Subjek, Tempat Dan Waktu Penelitian}

Mata pelajaran yang menjadi subjek penelitian adalah matematika dengan operasi bilangan. Subjek dalam penelitian adalah siswa kelas 1 SD Negeri 1 Sandik dengan jumlah siswa 32 orang terdiri dari 18 laki-laki dan 14 perempuan.

\section{Prosedur Penelitian}

Pada gambar di atas, dapat dilihat bahwa dalam melaksanakan perbaikan pembelajaran, peneliti menggunakan prinsip Penelitian Tindakan Kelas yang terdiri dari tiga siklus. Masing-masing siklus dilaksanakan melalui tahapan perencanaan, pelaksanaan tindakan, observasi dan refleksi.

\section{Metode Pengumpulan Data}

\section{a. Metode Test}

Test adalah merupakan alat prosedur yang digunakan, alat ini berbentuk tugastugas atau suruhan-suruhan yang harus dilaksanakan (Gafur, 2018. Tes dapat pula berupa pertanyaan baik secara lisan maupun tertulis (Gafur, 2018; Nurjanah \& Marlianingsih, 2015). Dengan demikian disimpulkan bahwa test adalah suatu prosedur atau keterangan yang diinginkan tentang seseorang dengan cara memberikan pertanyaan (soal) atau serangkaian tugastugas yang dikerjakan.

\section{b. Metode wawancara/interview}

Wawancara/interview adalah suatu dialog yang dilakukan oleh pewawancara (Arikunto, 2010). Pendapat lain mengatakan bahwa wawancara adalah suatu teknik pengumpulan data yang dilakuan dengan cara tanya jawab anata penanya atau pewawancara dengan responden/penjawab (Sugiyono, 2012).

\section{Analisis Data}

Metode yang digunakan dalam pengolahan data yaitu metode diskriptif, metode ini diterapakan dalam pengolahan data berdasarkan model dan jenis pelaksanaan metode ini. Cara metode diskriptif adalah data yang dikumpulkan mula-mula disusun dijelaskan kemudian dianalisa, karena itu metode ini disebut juga metode analitik (Wardani \& Solikah, 2017).

Dalam penelitian ini diperoleh data berupa angka-angka (hasil dari test) tentang Efetivitas penggunaan Dwibahasa dalam proses pembelajaran Matematika di SD Negeri 1 Sandik tahun 2019, maka analisa data yang digunakan adalah:

a. Menghitung (Y) efektifitas Penggunaan Dwibahasa, dalam proses pembelajaran Matematika di kelas 1 SD Negeri 1 Sandik tahun pelajaran 2018/2019

b. Mendiskrifsikan/menerjemahkan arti efektifitas yang diperoleh siswa dalam proses pembelajaran dengan menggunakan interval sebagai berikut:

1. Antara $76 \%-100 \%$ artinya baik

2. Antara $56 \%-75 \%$ artinya cukup

3. Antara $40 \%-55 \%$ artinya kurang baik

4. Kurang dari $40 \%$ artinya tidak baik (Arikunto, 1998) 
c. Indikator Ketuntasan

Penelitian ini dinyatakan berhasil jika siswa yang mencapai katagori baik sebanyak $85 \%$.

\section{Hasil dan Pembahasan}

\section{Siklus I}

a. Tahap Perencanaan

Pada tahap ini peneliti mempersiapkan perangkat pembelajaran yang terdiri dari rencana pelajaran 1 , LKS 1 , soal tes formatif 1 dan alat-alat pengajaran yang mendukung. Selain itu juga dipersiapkan lembar observasi pengolaan pembelajaran.

\section{b. Tahap Kegiatan dan Pelaksanaan}

Pelaksanaan kegiatan belajar mengajar untuk siklus I dilaksanakan pada tanggal 14 s.d 19 Januari 2019 di kelas 1 SD Negeri 1 Sandik dengan jumlah siswa 32 orang. Dalam hal ini peneliti bertindak sebagai guru. Adapun proses belajar mengajar mengacu pada rencana pelajaran yang telah dipersiapkan.

Pengamatan (observasi) dilaksanakan bersamaan dengan pelaksaaan belajar mengajar. Pada akhir proses belajar mengajar siswa diberi post tes dengan tujuan untuk mengetahui tingkat efektifitas siswa dalam proses belajar mengajar menggunakan dwibahasa. Adapun data hasil penelitian pada siklus I. adalah nilai post tes sebesar 73,95\% dan dari 32 siswa yang telah masuk katagori baik sebanyak 9 siswa, 22 orang siswa belum mencapai katagori cukup sedangkan yang masuk katagori kurang baik 1 orang siswa. Sedangkan ketuntasan klasikal belajar sebesar $28,15 \%$, hasil ini belum mencapai indikator ketuntasan $85,00 \%$. Hasil pada siklus I ini belum mengalami peningkatan maka dilanjutkan ke siklus II.

\section{c. Refleksi}

Dalam pelaksanaan kegiatan belajar mengajar diperoleh informasi dari hasil pengamatan sebagai berikut:
Kegagalan siklus I bermuara pada cara guru menyajikan pembelajaran yang kurang menarik. Guru tidak merata melakukan bimbingan, siswa dalam diskusi masih bermain-main.

Pelaksanaan kegiatan belajar mengajar pada siklus I ini masih terdapat kekurangan, sehingga perlu adanya revisi untuk dilakukan pada siklus berikutnya. 1) Guru perlu lebih terampil dalam memotivasi siswa dan lebih jelas dalam menyampaikan tujuan pembelajaran. Di mana siswa diajak untuk terlibat langsung dalam setiap kegiatan yang akan dilakukan; 2) Guru perlu mendistribusikan waktu secara baik dengan menambahkan informasi-informasi yang dirasa perlu dan memberi catatan; 3) Guru harus lebih terampil dan bersemangat dalam memotivasi siswa sehingga siswa bisa lebih antusias. Perhatian dan bimbingan perlu menjadi perhatian yang utama. Semua kelemahan pada siklus I menjadi bahan acuan bagi guru untuk melakukan perbaikan pada siklus II.

\section{Siklus II}

\section{a. Tahap Perencanaan}

Pada tahap ini peneliti mempersiapkan perangkat pembelajaran yang terdiri dari rencana pelajaran 2, soal Post tes II dan alatalat pengajaran yang mendukung.

b. Tahap kegiatan dan pelaksanaan

Pelaksanaan kegiatan belajar mengajar untuk siklus II pada tanggal 21 s.d 26 Januari 2018 di kelas 1 SD Negeri 1 Sandik dengan jumlah siswa 32 orang. Dalam hal ini peneliti bertindak sebagai guru. Adapun proses belajar mengajar mengacu pada rencana pelajaran dengan memperhatikan revisi pada siklus I, sehingga kesalahan atau kekurangan pada siklus I tidak terulang lagi pada siklus II. Pengamatan (observasi) dilaksanakan bersamaan dengan pelaksanaan belajar mengajar. Pada akhir proses belajar mengajar siswa diberi post tes II dengan tujuan untuk mengetahui tingkat keberhasilan siswa dalam proses belajar mengajar yang telah dilakukan 
dengan bahasa pengantar dwibahasa. Instrumen yang digunakan adalah post tes II. Adapun data hasil penelitian pada siklus II adalah diperoleh persentase nilai post tes sebesar 75,93\% yang telah masuk katagori baik sebanyak 26 siswa 6 orang siswa belum mencapai katagori cukup dan ketuntasan klasikal sebesar $81,25 \%$ atau 26 siswa dari 32 siswa,. Tetapi secara klasikal ketuntasan belajar belum mencapai indikator ketuntasan $85,00 \%$. Hasil pada siklus II ini sudah mengalami peningkatan tetapi belum mencapai indikator keberhasilan maka perbaikan pembelajaran dilanjutkan ke siklus III.

\section{c. Refleksi}

Dalam pelaksanaan kegiatan belajar diperoleh informasi dari hasil pengamatan sebagai berikut: Memotivasi siswa belum maksimal, Membimbing siswa merumuskan kesimpulan perlu ditingkatkan. Pengelolaan waktu belajar perlu menjadi perhatian guru. Pelaksanaan kegiatan belajar pada siklus II ini masih terdapat kekurangan-kekurangan. Maka perlu adanya revisi untuk dilaksanakan pada siklus III antara lain: Guru harus lebih sabar dalam membimbing siswa merumuskan kesimpulan. Guru harus mendistribusikan waktu secara baik sehingga kegiatan pembelajaran dapat berjalan sesuai dengan yang diharapkan. Guru dalam memotivasi siswa hendaknya dapat membuat siswa lebih termotivasi selama proses belajar mengajar berlangsung. Guru harus lebih dekat dengan siswa sehingga tidak ada perasaan takut dalam diri siswa baik untuk mengemukakan pendapat atau bertanya. Guru sebaiknya menambah lebih banyak contoh alat permainan dan memberi soal-soal latihan pada siswa untuk dikerjakan pada setiap kegiatan belajar mengajar.

\section{Siklus III}

\section{a. Tahap Perencanaan}

Pada tahap ini peneliti mempersiapkan perangkat pembelajaran yang terdiri dari rencana pelajaran 3 , soal post tes 3 dan alatalat pengajaran yang mendukung terlaksananya proses belajar mengajar di kelas. Memantapkan kompetensi guru terutama dalam menggunakan bahasa pengantar yaitu dwibahasa.

\section{b. Tahap kegiatan dan pengamatan}

Pelaksanaan kegiatan belajar mengajar untuk siklus III pada tanggal 5 s.d 9 Pebruari 2019 di kelas 1 SD Negeri 1 Sandik dengan jumlah siswa 32 orang Adapun proses belajar mengajar mengacu pada rencana pelajaran dengan memperhatikan revisi pada siklus II, sehingga kesalahan atau kekurangan pada siklus II tidak terulang lagi pada siklus III. Pengamatan (observasi) dilaksanakan bersamaan dengan pelaksanaan belajar mengajar.

Pada akhir proses belajar mengajar siswa diberi post tes III dengan tujuan untuk mengetahui tingkat keberhasilan siswa dalam proses belajar mengajar menggunakan bahasa pengantar dwibahasa. Instrumen yang digunakan adalah soal post tes III. Adapun data hasil penelitian pada siklus III adalah diperoleh persentase nilai post tes sebesar $87,81 \% 87,81 \%$ dan dari 32 siswa yang telah masuk katagori baik sebanyak 29 siswa, 3 orang siswa mencapai katagori cukup. Tetapi secara klasikal ketuntasan belajar telah mencapai indikator ketuntasan 90,62\%. Hasil pada siklus III ini telah mengalami peningkatan lebih baik dari siklus II. Adanya peningkatan hasil belajar pada siklus III ini dipengaruhi oleh adanya peningkatan kemampuan guru dalam menerapkan pembelajaran melalui penggunaan bahasa pengantar dengan dwibahasa, sehingga siswa menjadi lebih terbiasa dengan pembelajaran seperti ini sehingga siswa lebih mudah dalam memahami materi yang telah diberikan. Di samping itu ketuntasan ini juga dipengaruhi oleh kerja sama dari siswa yang telah menguasai materi pelajaran untuk mengajari temannya yang belum menguasai. 
Menghitung Persentase (\%) Efektivitas Penggunaan Dwibahasa Dalam Proses Pembelajaran Matematika di Kelas 1 SD Negeri 1 Sandik. Dari data pada di atas dapat kita ketahui bahwa penggunaan dwibahasa dalam proses pembelajaran Matematika di kelas1 SD Negeri 1 Sandik pada siklus I, Kualitasnya cukup dan belum tuntas.

Menghitung Persentase (\%) Efektivitas Penggunaan Dwibahasa Dalam Proses Pembelajaran Matematika di Kelas 1 SD Negeri 1 Sandik pada siklus II. Dari data di atas dapat kita ketahui bahwa Penggunaan dwibahasa Dalam Proses Pembelajaran Matematika di Kelas 1 SD Negeri 1 Sandik menunjukkan Persentase ketuntasan penggunaan dwibahasa dalam proses pembelajaran yaitu 26 siswa dari 32 siswa atau 81,25\%. Persentase ketidaktuntasan penggunaan dwibahasa dalam proses pembelajaran yaitu 6 siswa dari 32 siswa atau $18,75 \%$. Hal ini menjelaskan bahwa Efektivitas penggunaan dwibahasa dalam proses pembelajaran Matematika di kelas1 SD Negeri 1 Sandik, sudah mengalami peningkatan tetapi kualitasnya belum beranjak dari cukup serta indikator ketuntasan klasikalnya belum tercapai maka penelitian ini dilanjutkan pada siklus III.

Menghitung Persentase (\%) Efektivitas Penggunaan Dwibahasa dalam Proses Pembelajaran Matematika di Kelas 1 SD Negeri 1 Sandik pada siklus III. Dari data di atas dapat kita ketahui bahwa Penggunaan Dwibahasa dalam Proses Pembelajaran Matematika di Kelas 1 SD Negeri 1 Sandik pada siklus II bisa digambarkan bahwa: a) Persentase ketuntasan penggunaan dwibahasa dalam proses pembelajaran yaitu 29 siswa dari 32 siswa atau 90,62 \%; b) Persentase tidak tuntasan penggunaan dwibahasa dalam proses pembelajaran yaitu 3 siswa dari 32 siswa atau $9,38 \%$. Hal ini menunjukkan bahwa efektivitas penggunaan dwibahasa dalam proses pembelajaran Matematika di kelas SD Negeri 1 Sandik, pada siklus III telah memenuhi indikator ketuntasan dimana kualitasnya baik melampaui $85 \%$ yaitu 90,62\%,

Berdasarkan pembahasan di atas maka dapat disimpulkan bahwa Efektivitas penggunaan dwibahasa dalam proses pembelajaran Matematika di kelas 1 SD Negeri 1 Sandik telah memenuhi indikator ketuntasan dimana kualitasnya baik melampaui $85 \%$ yaitu 90,62\% maka perbaikan pembelajaran ini dinyatakan tuntas dan hipotesis tindakan dinyatakan diterima yaitu sangat efektif penggunaan Dwibahasa dalam proses pembelajaran Matematika di kelas 1 SD Negeri 1 Sandik

\section{Kesimpulan}

Berdasarkan hasil penelitian dapat disimpulkan bahwa efektivitas penggunaan dwibahasa dalam proses pembelajaran Matematika di kelas 1 SD Negeri 1 Sandik telah memenuhi indikator ketuntasan dimana kualitasnya baik melampaui $85 \%$ yaitu $90,62 \%$ maka perbaikan pembelajaran ini dinyatakan tuntas dan hipotesis tindakan dinyatakan diterima yaitu sangat efektif penggunaan Dwibahasa dalam proses pembelajaran Matematika di kelas SD Negeri 1 Sandik.

\section{Daftar Pustaka}

Arikunto, S. (2010). Prosedur Penelitian Suatu Pendekatan Praktek. Rineka Cipta.

Gafur, A. (2018). Peningkatan Hasil Belajar IPA Terpadu Melalui Metode Demonstrasi Pada Siswa Kelas VIII SMP Negeri 2 Sano Nggoang Manggarai Barat Tahun Pelajaran 2017/2018. Jisip, 2(1), 144-161.

Junaidi, J. (2019). Peran Media Pembelajaran Dalam Proses Belajar Mengajar. Diklat Review: Jurnal Manajemen Pendidikan Dan Pelatihan, 3(1), 45-56. https://doi.org/10.35446/diklatreview.v $3 \mathrm{i} 1.349$

Nurjanah, \& Marlianingsih, N. (2015). Analisis Butir Soal Pilihan Ganda Dari Aspek 
Kebahasaan. Faktor Jurnal Ilmu Kependidikan, 2(1), 69-78.

Sugiyono. (2012). Metode Penelitian Kuantitatif Kualitatif Dan RED. Alfabeta.

Umarella, S., Saimima, M. S., \& Husein, S. (2018). Urgensi Media Dalam Proses Pembelajaran. Al-Iltizam: Jurnal Pendidikan Agama Islam, 3(2), 237. https://doi.org/10.33477/alt.v3i2.605

Wardani, I., \& Solikah, U. N. (2017). Strategi Pemasaran Keripik Belut Di Industri Rumah Tangga Sari Roso Kecamatan Baki Kabupaten Sukoharjo. AGRONOMIKA, 12(1). 